\title{
DYNAMIC CHARACTERISTICS OF THE WALL STRUCTURE DURING THE HEAT TRANSFER PROCESS
}

\author{
UDC 691.421.4:536.2
}

\author{
Saša Kalinović, Jelena Đoković, Dejan Tanikić \\ Technical Faculty in Bor, University of Belgrade, Bor, Serbia
}

\begin{abstract}
This paper deals with the impact of high-density thermal mass materials of the wall structure on the dynamic characteristics of a multi-layered building envelope during the heat transfer process. Since the final objective is to design the most energyefficient building, i.e. a building with the lowest heating and cooling energy consumption, it is necessary to achieve good thermal performances of a multi-layered wall. In order to find the optimal wall structure solution with the highest energy-saving potential, different wall structures with different layer thicknesses were analyzed, along with walls of the same structure with different positions of individual thermo insulating layers within the wall. Based on the results presented in this paper, it can be concluded that at walls with similar structures and the same total thickness, but different layer thicknesses that make up the complete structure of the wall, there are differences in delaying external temperature changes on the wall. However, the position of the thermal insulation layer does not significantly affect temperature oscillation amplitude caused by external temperature change.
\end{abstract}

Key words: thermal mass, specific wall mass, thermal absorption, periodic heat transfer, reduction factor, thermal inertia

\section{INTRODUCTION}

Residential and commercial building materials have to meet requirements such as durability, maintainability and accessibility. They must be not only strong enough to meet structural and seismic requirements, but to satisfy esthetic demands as well. The choice of materials used for the construction of a building envelope also affects its energy efficiency.

The temperature and intensity of solar radiation change constantly during the day, and the building envelope should not be considered as a simple barrier between the internal and external space. Even when the heating and cooling of the building are sufficient to

Received January 13, 2020 / Accepted April 16, 2020

Corresponding author: Saša Kalinović

Technical Faculty in Bor, 12 Vojske Jugoslavije, 19210 Bor, Serbia

E-mail: kalinovicsasa@yahoo.com 
compensate for the poorly insulated or permeable building envelope, the inner surfaces can be cold or warm, which affects their radiation in the room. That is why the dynamic behavior of the building envelope is analyzed, i.e. the influence of the thermal mass on the stability of the temperature conditions in the interior of the building.

The thermal mass is the ability of a material to absorb, store and then gradually release accumulated thermal energy. The thermal mass is a concept in building design that describes the building mass resistance to temperature fluctuations. This is known as the thermal flywheel effect. Since the outdoor temperature changes constantly during the day, a large thermal mass within the insulated part of the building can even out daily temperature fluctuations. The thermal mass will absorb the heat when the outdoor temperature is higher than the indoor temperature and then release accumulated heat energy when the surroundings are cooler, without reaching the thermal equilibrium. The thermal mass reduces the building's thermal conductivity, thus enabling the inside of a building to be heated or cooled relatively independently of the environment.

In order to get the highest thermal mass benefits, it is essential that the thermal mass should be located within the insulated space; the orientation of the building must be such as to enable thermal mass to be exposed to direct sunlight; windows must be properly sized; the thermal mass must not be insulated from the heat source; a building must be well insulated, and the surface of thermal mass must be dark and textured.

Many researchers have studied the problem of the thermal mass influence on the heat transfer characteristics. Evangelisti, et al. [1] calculated the overall heat transfer coefficient in various cases by measuring physical parameters necessary to define the heat transfer coefficient. The differences between coefficient values, as well as their impact on thermal conductivity calculations were analyzed in order to gain a better understanding and application of the UNI EN ISO 6946 standard. In the paper [2] a method based on an analogy with electrical conductivity was presented and that method was used to analyze the equivalent wall of three homogenous layers which have the same thermodynamic behavior as the thermal bridge. Biddulpha, et al. [3] considered the combination of concentrated thermal mass model and Bayesian statistical analysis for estimating the U-value and effective thermal mass. Furniture and other internal content can have a significant impact on the indoor thermal dynamics and the occupant's comfort. Representative values for the furniture parameters, e.g. indoor thermal mass, obtained by applying different models were shown in the paper [4]. It was concluded that the large exposed surface area of furniture pieces can significantly increase the effective heat inertia of a building without any construction work. Ferrari and Zanotto [5] showed that non-stationary heat transfer processes between the building and the environment, i.e. the calculation of the dynamic behavior of a building allows for a realistic assessment of its thermal characteristics. The method presented in this paper introduces some new parameters in the thermal analysis: thermal capacity and inertia of the envelope, a phase shift of the oscillation of the outside temperature and the factor of weakening of these oscillations. In the paper [6], the impact of the wall structure on its dynamic characteristics was analyzed. It was noticed that the heat transfer coefficients were approximate although the total specific masses of the walls were different.

In this paper, dynamic characteristics of certain types of walls have been analyzed in order to find the best possible solutions that follow legislative compliance and meet criteria defined by The Rulebook on Energy Efficiency of Buildings, Official Gazette of the Republic of Serbia No. 61/2011 [7]. 


\section{PROBLEM Formulation}

The increase in the heat accumulation capacity of the building envelope is achieved by using materials with larger values of median material density, and with the specific heat capacity of partition walls. Hence, a more stable internal temperature will be generated.

The thermal mass is an extremely important feature of the envelope which affects the thermal performances of a building. It causes a delay in the temperature profile, $\varphi$ and attenuates heat transfer, as shown in Figure 1, [8].

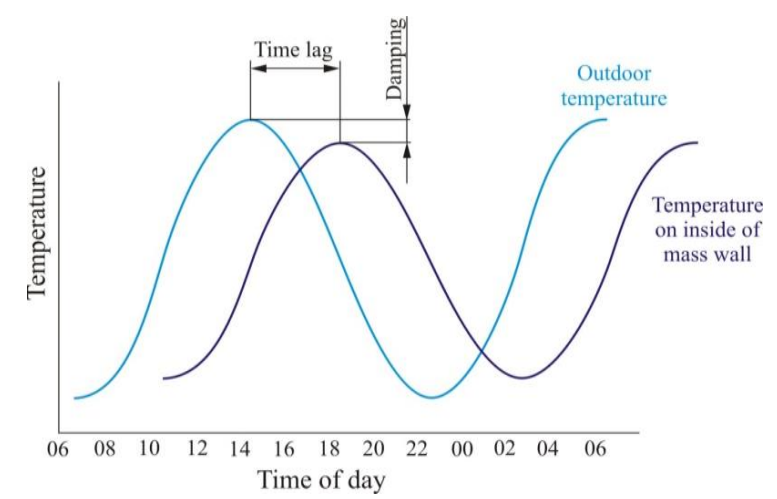

Fig. 1 Temperature profile as a function of time

The time lag between the maximal external and internal temperature depends on the thermal capacity of the building, $C_{m}$ and other characteristics, Figure 2, [9].

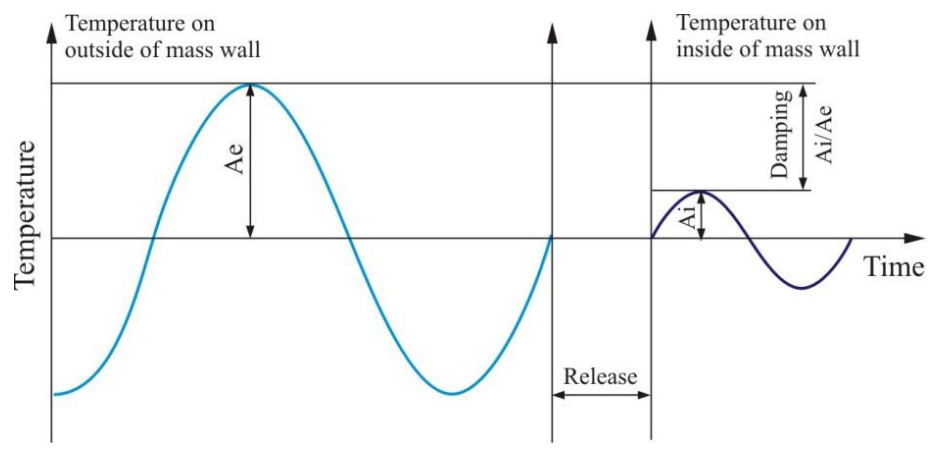

Fig. 2 Sinusoidal temperature variations function

The thermal capacity of the solid coating elements defines the phase shift or the ability to temporarily delay the external thermal effect, while the attenuation factor is the ratio of the oscillation amplitude of the external and internal temperatures. If a wall element, separating the zones $m$ and $n$, is observed, Figure 3, the law of temperature change can be written, [11]. 


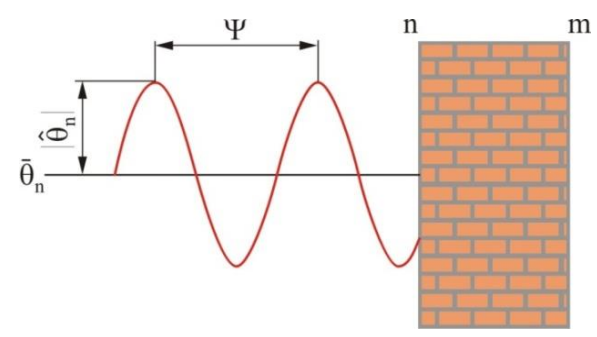

Fig. 3 The law of temperature change

Temperature is changed according to the law:

$$
\theta_{n}(t)=\bar{\theta}_{n}+\left|\hat{\theta}_{n}\right| \cos (\omega t+\psi)=\bar{\theta}_{n}+\frac{1}{2}\left[\hat{\theta}_{+n} e^{j \omega t}+\hat{\theta}_{-n} e^{j \omega t}\right]
$$

where: $\bar{\theta}_{n}$ - average values of temperature, $\left|\hat{\theta}_{n}\right|$ - amplitude of temperature oscillations, $\omega$ - angular frequency of oscillations, $\hat{\theta}_{ \pm n}$ - complex amplitude of temperature oscillations defined by: $\bar{\theta}_{ \pm n}=\left|\hat{\theta}_{n}\right| e^{ \pm j \psi}$.

The attenuation factor indicates the ability of the wall to reduce the outside temperature extremes on the inside of the wall and to delay the heat transfer process, i.e. to act as a real heat buffer.

The calculation of the dynamic behavior of a building is carried out according to EN ISO 13786 [11]. The wall with a homogenous isotropic structure with a sinusoidal variation of the external temperature around its long-term average value is observed, see Figure 3.

Fourier's equation for conducting heat:

$$
\frac{\partial^{2} \theta}{\partial x^{2}}=\frac{1}{\alpha} \frac{\partial \theta}{\partial \tau}
$$

where $\alpha$ is the thermal diffusivity, has a solution in the form:

$$
\theta_{1}=c_{1} e^{x}+c_{2} e^{-x}
$$

The relation between heat flux and temperature is:

$$
q=-\lambda \frac{\partial \theta}{\partial x}
$$

where $\lambda$ is the thermal conductivity, boundary conditions on surfaces $m$ and $n$ are, see Figure 4:

$$
\begin{aligned}
& \hat{\theta}_{n}(0)=\hat{\theta}_{n} \\
& \hat{q}_{n}(0)=\hat{q}_{n} \\
& \hat{\theta}_{n}(d)=\hat{\theta}_{m} \\
& \hat{q}_{n}(d)=\hat{q}_{m}
\end{aligned}
$$




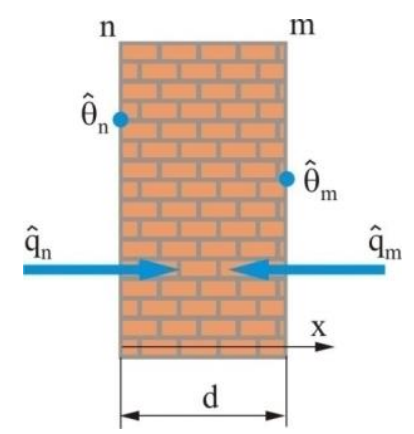

Fig. 4 Boundary conditions.

Correlation of the heat flux and temperature from one to the opposite side of the wall is:

$$
\left(\begin{array}{l}
\hat{\theta}_{m} \\
\hat{q}_{m}
\end{array}\right)=\left[\begin{array}{ll}
Z_{11} & Z_{12} \\
Z_{21} & Z_{22}
\end{array}\right]\left(\begin{array}{l}
\hat{\theta}_{n} \\
\hat{q}_{n}
\end{array}\right)
$$

The complex coefficients $Z_{m n}$ of the heat transfer are calculated according to:

$$
\begin{gathered}
Z_{11}=Z_{22}=\cosh (\xi) \cos (\xi)+j \sinh (\xi) \sin (\xi) \\
Z_{12}=-\frac{\delta}{2 \lambda}\{[\sinh (\xi) \cos (\xi)+\cosh (\xi) \sin (\xi)]+j[\cosh (\xi) \sin (\xi)-\sinh (\xi) \cos (\xi)]\} \\
Z_{21}=-\frac{\delta}{\lambda}\{[\sinh (\xi) \cos (\xi)-\cosh (\xi) \sin (\xi)]+j[\sinh (\xi) \cos (\xi)+\cosh (\xi) \sin (\xi)]\}
\end{gathered}
$$

where the periodic penetration depth $\delta$ for homogeneous material and sinusoidal change is:

$$
\delta=\sqrt{\frac{\lambda T}{\pi \rho c}}
$$

and

$$
\xi=\frac{d}{\delta}
$$

where $d$ is the thickness of the wall.

The matrix of the heat exchange of building elements between the two surfaces is:

$$
\boldsymbol{Z}=\left(\begin{array}{ll}
Z_{11} & Z_{12} \\
Z_{21} & Z_{22}
\end{array}\right)=Z_{N} Z_{N-1} \ldots Z_{3} Z_{2} Z_{1}
$$

where $Z_{1}, Z_{2}, Z_{3}, \ldots Z_{n}$ are matrices of the heat exchange of individual layers of the building structure starting from layer 1 .

The matrix of the heat transfer from the environment to the inside of the building through the building structure is: 


$$
Z_{e e}=Z_{s 2} Z Z_{s 1}
$$

where $Z_{s 1}$ and $Z_{s 2}$ are matrices of the heat transfer through the boundary layers:

$$
Z_{s i}=\left(\begin{array}{cc}
1 & -R_{s i} \\
0 & 1
\end{array}\right)
$$

where $R_{s i}$ is the resistance of the surface of the i-th boundary layer, which involves convection and radiation.

The thermal absorption, $Y_{m m}$, is the complex number which is defined as the amplitude of the heat flow through the component surface facing the zone $m$ relative to the amplitude of the temperature variation in the same zone, when the temperature on the other side is constant. In this case, $Y_{11}$ refers to the inner and $Y_{22}$ to the outer layer side, that is:

$$
\begin{gathered}
Y_{n m}=\left.\frac{\hat{q}_{m}}{\hat{\theta}_{m}}\right|_{\hat{\theta} n=0}, \\
Y_{11}=\left.\frac{\hat{q}_{1}}{\hat{\theta}_{1}}\right|_{\hat{\theta}_{2}=0}=-\frac{Z_{11}}{Z_{12}}, Y_{12}=\left.\frac{\hat{q}_{2}}{\hat{\theta}_{2}}\right|_{\hat{\theta}_{1}=0}=-\frac{Z_{22}}{Z_{12}}
\end{gathered}
$$

The periodic heat transfer, $Y_{m n}$, is the complex number that is defined as the amplitude of the heat flow through the component surface facing the $m(n)$ zone, relative to the amplitude of the temperature variation in the zone $n(m)$, when the temperature in the zone $m(n)$ is constant:

$$
Y_{m n}=\left.\frac{\hat{q}_{n}}{\hat{\theta}_{m}}\right|_{\hat{\theta}_{n}=0}, Y_{12}=\frac{1}{Z_{12}}, Y_{21}=\frac{1}{Z_{21}}
$$

The heat capacity, $k_{m}$, is the ratio between the heat capacity and the surface of the element under consideration:

$$
k_{m}=\frac{C_{m}}{A}=\frac{1}{\omega}\left|Y_{m m}-Y_{m n}\right|
$$

The heat capacity for a component that separates the two zones is:

$$
k_{1}=\frac{T}{2 \pi}\left|\frac{Z_{11}-1}{Z_{12}}\right|, k_{2}=\frac{T}{2 \pi}\left|\frac{Z_{22}-1}{Z_{12}}\right|
$$

A factor of attenuation of external temperature oscillations, $f$, is a ratio between the periodic heat transfer and the thermal transfer, $U_{0}$, according to UNI EN ISO 6946 without considering the thermal bridges:

$$
f=\left|\frac{\hat{q}_{2}}{\hat{\theta}_{1}}\right| \frac{1}{U_{0}}=\frac{\left|Y_{12}\right|}{U_{0}}
$$




\section{RESULTS AND DISCUSSION}

Hereafter, dynamic characteristics of the heat transfer in walls with different structures have been analyzed.

The calculation of dynamic characteristics of the walls, that is, the calculation of values defining dynamic behavior of the walls includes: identifying materials that form the layers of the building component, the thickness of these layers and the thermal characteristics of the material; determining the period of temperature variations on surfaces; calculation of penetration depth for the material of each layer; determining the heat transfer matrix for each layer (component); multiplying the heat transfer matrix of each layer, excluding the peripheral layers, in the correct order to obtain the heat transfer matrix of the wall.

Three types of walls with similar structures - the same total thickness, but different layer thicknesses that make up the complete structure of the wall, are examined in this paper, as well as three cases of the same wall, but with the different positions of the thermal insulation layer.

Figure 5 shows three types of walls with similar structures, with the same total thickness, but with different layer thicknesses that make up the complete structure of the wall.

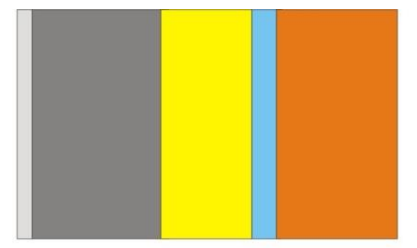

$\square$ longitudinal lime mortar

concrete with stone aggregates

$\square$ thermal insulation-stone woo

$\square$ air layer

synthetic board made of multilayer polyester

a)

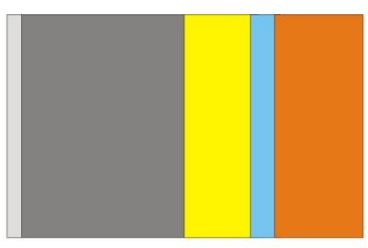

$\square$ longitudinal lime mortar concrete with stone aggregates sulation-stone wool

$\square$ air layer

b)

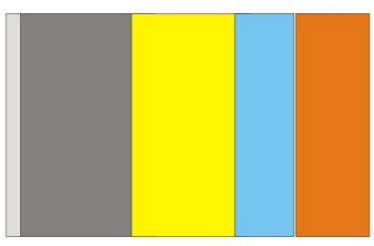

$\square$ longitudinal lime mortar concrete with stone aggregates thermal insulation-stone wo air layer

Fig. 5 Structure of the walls: a) wall 1, b) wall 2 and c) wall 3

The structure of the walls shown in Figure 5 is given in Table 1.

Table 1 Structure of the walls

\begin{tabular}{llll}
\hline \multirow{2}{*}{\multicolumn{1}{c}{ Structure of the wall }} & \multicolumn{3}{c}{ Layer thickness [m] } \\
\cline { 2 - 4 } & Wall 1 & Wall 2 & Wall 3 \\
\hline Longitudinal lime mortar & 0.015 & 0.01 & 0.015 \\
Concrete with stone aggregates & 0.15 & 0.2 & 0.1 \\
Thermal insulation-stone wool & 0.1 & 0.08 & 0.150 \\
Air layer & 0.04 & 0.035 & 0.08 \\
Synthetic board made of multilayer polyester & 0.12 & 0.1 & 0.08 \\
\hline
\end{tabular}


The basic characteristics of the walls shown in Figure 5 are given in Table 2.

Table 2 Basic characteristics of walls

\begin{tabular}{lccc}
\hline & Wall 1 & Wall 2 & Wall 3 \\
\hline Thickness $[\mathrm{m}]$ & 0.425 & 0.425 & 0.425 \\
Heat transfer coefficient, $\mathrm{U}\left[\mathrm{W} / \mathrm{m}^{2} \mathrm{~K}\right]$ & 0.197 & 0.233 & 0.13 \\
Mass $\left[\mathrm{kg} / \mathrm{m}^{2}\right]$ & 576 & 642 & 460 \\
\hline
\end{tabular}

Dynamic characteristics of the walls shown in Figure 5 are given in Table 3.

Based on results shown in Table 3, it can be noticed that differences in the heat transfer coefficients between walls 1 and 2 are almost twice smaller than between walls 2 and 3 , while the specific mass of the walls varies considerably.

It can also be noticed that the phase shift at the inner and the outer side of the wall is approximately equal for all the walls, while that value is smaller between walls 1 and 2 . This means that walls, on all coatings, react to changes in the outside temperature at almost the same speed.

Table 3 Dynamic characteristics of the walls

\begin{tabular}{lccc}
\hline Dynamic characteristics & Wall 1 & Wall 2 & Wall 3 \\
\hline Thermal absorption on the inner side of the wall, $\mathrm{Y}_{11}\left[\mathrm{~W} / \mathrm{m}^{2} \mathrm{~K}\right]$ & 5.572 & 5.482 & 5.733 \\
& $(1.01 \mathrm{~h})$ & $(0.92 \mathrm{~h})$ & $(1.35 \mathrm{~h})$ \\
& 4.739 & 4.78 & 4.916 \\
& $(2.46 \mathrm{~h})$ & $(2.43 \mathrm{~h})$ & $(2.45 \mathrm{~h})$ \\
& 0.003 & 0.005 & 0.001 \\
& $(1.17 \mathrm{~h})$ & $(2.71 \mathrm{~h})$ & $(-1.42 \mathrm{~h})$ \\
& 76.6 & 75.3 & 78.8 \\
Periodic heat transfer, $\mathrm{Y}_{12}\left[\mathrm{~W} / \mathrm{m}^{2} \mathrm{~K}\right]$ & 65.1 & 65.7 & 67.6 \\
& 0.015 & 0.02 & 0.01 \\
Heat capacity of the inner surface of the wall, $\mathrm{k}_{1}\left[\mathrm{~kJ} / \mathrm{m}^{2} \mathrm{~K}\right]$ & 22.83 & 21.29 & 1.42 \\
Heat capacity of the outer surface of the wall, $\mathrm{k}_{2}\left[\mathrm{~kJ} / \mathrm{m}^{2} \mathrm{~K}\right]$ & & &
\end{tabular}

The thermal conductivity - the ratio between the heat capacity and the surface of the observed element - of the outer wall surface $k_{m}\left(k_{2}\right)$, has the highest value for the wall 3 , while for the walls 2 and 3 the values are smaller and approximate $\left(65.1 \mathrm{~kJ} / \mathrm{m}^{2} \mathrm{~K}\right.$ and $65.7 \mathrm{~kJ} / \mathrm{m}^{2} \mathrm{~K}$, respectively).

The attenuation factor of the external temperature oscillation amplitude is the highest in the case of wall $2(0.02)$; the value of oscillation attenuation factor for the wall 1 is $25 \%$ smaller than for the wall 2 , while the value for the wall 3 is twice smaller $(0.01)$ compared to the wall 2.

As a consequence, the delay in changing the outside temperature for the wall 3 is 16 times smaller $(1.42 \mathrm{~h})$ than for the walls 1 and 2 ( $22.83 \mathrm{~h}$ and $21.29 \mathrm{~h}$, respectively).

On the account of the influence of the position of thermal insulation in the wall, three cases of the same wall with three different positions of thermal insulation are analyzed.

In Figure 6 different positions of concrete layers and thermal insulation are shown, in order to investigate the influence of the position of thermal insulation in the wall. 


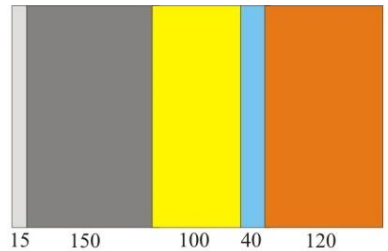

$\square$ longitudinal lime mortar

concrete with stone aggregates

thermal insulation-stone woo

a air laye

synthetic board made of multilayer polyester

a)

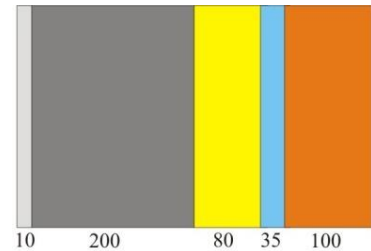

$\square$ longitudinal lime mortar

$\square$ concrete with stone aggregates

thermal insulation-stone wool

air layer

synthetic board made of multilayer polyester

b)

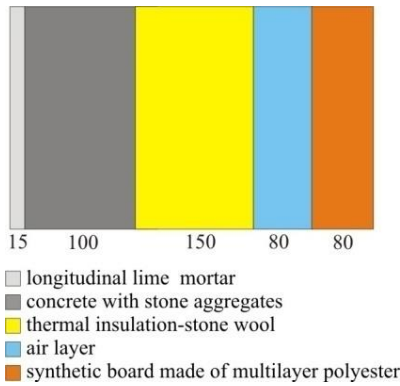

c)

Fig. 6 Structure of walls with different positions of thermal insulation: a) wall 4, b) wall 5 and c) wall 6

The basic characteristics of the walls shown in Figure 6 are given in Table 4 .

Table 4 Basic characteristics of walls

\begin{tabular}{|c|c|c|c|}
\hline & Wall 4 & Wall 5 & Wall 6 \\
\hline Thickness [m] & & 0.425 & \\
\hline Heat transfer coefficient, $\mathrm{U}\left[\mathrm{W} / \mathrm{m}^{2} \mathrm{~K}\right]$ & & 0.197 & \\
\hline Mass $\left[\mathrm{kg} / \mathrm{m}^{2}\right]$ & & 576 & \\
\hline
\end{tabular}

Dynamic characteristics of the walls shown in Figure 6 are given in Table 5.

Based on the results shown in Table 5 it can be noticed that the values of the attenuation factors of the temperature oscillations range from 0.004 to 0.016 .

Regarding the delay in temperature changes, it ranges from $21.94 \mathrm{~h}$ to $22.83 \mathrm{~h}$. The smallest delay is at wall $6(21.94 \mathrm{~h})$, while it is slightly larger at walls 4 and $5(22.83 \mathrm{~h}$ and $22.74 \mathrm{~h}$, respectively).

This means that at the wall 4 temperature oscillation will be changed, which is caused by the outer temperature change $0.89 \mathrm{~h}$ later than at the wall 6 .

All these show that the best configuration of concrete and thermal insulation is at the wall 4 . Thus, the combination of basic and insulation materials gives the best solution regarding the dynamic behavior of these walls.

Similar results were shown in [6]. They showed that thermal conductivity has the largest value for the heavy full brick wall, and the value for the hollow brick wall is, as expected, ten times higher than for the light wall made of an insulation sandwich panel. According to them the attenuation factor of the external temperature oscillation amplitude is the highest in the case of a full brick wall, almost three times smaller for a hollow brick wall, and for the panel almost does not exist (the amplitudes are almost equal because there is no heat accumulation). 
Table 5 Dynamic characteristics of the walls

\begin{tabular}{lccc}
\hline Dynamic characteristics & Wall 4 & Wall 5 & Wall 6 \\
\hline Thermal absorption on the inner side of the wall, $\mathrm{Y}_{11}\left[\mathrm{~W} / \mathrm{m}^{2} \mathrm{~K}\right]$ & 5.572 & 5.521 & 1.883 \\
& $(1.01 \mathrm{~h})$ & $(1 \mathrm{~h})$ & $(4.32 \mathrm{~h})$ \\
& 4.739 & 4.734 & 4.738 \\
Thermal absorption on the outer side of the wall, $\mathrm{Y}_{22}\left[\mathrm{~W} / \mathrm{m}^{2} \mathrm{~K}\right]$ & $(2.46 \mathrm{~h})$ & $(2.45 \mathrm{~h})$ & $(2.46 \mathrm{~h})$ \\
& 0.003 & 0.003 & 0.001 \\
Periodic heat transfer, $\mathrm{Y}_{12}\left[\mathrm{~W} / \mathrm{m}^{2} \mathrm{~K}\right]$ & $(1.17 \mathrm{~h})$ & $(1.26 \mathrm{~h})$ & $(2.06 \mathrm{~h})$ \\
& 76.6 & 75.9 & 25.9 \\
Heat capacity of the inner surface of the wall, $\mathrm{k}_{1}\left[\mathrm{~kJ} / \mathrm{m}^{2} \mathrm{~K}\right]$ & 65.1 & 65.1 & 65.1 \\
Heat capacity of the outer surface of the wall, $\mathrm{k}_{2}\left[\mathrm{~kJ} / \mathrm{m}^{2} \mathrm{~K}\right]$ & 0.015 & 0.016 & 0.004 \\
Attenuation factor of the external temperature oscillation amplitude, $\mathrm{f}[-]$ & 22.83 & 22.74 & 21.94 \\
Delay in changing the temperature factor, $\varphi[\mathrm{h}]$ & & &
\end{tabular}

\section{CONCLUSION}

In this paper, non-stationary processes of the heat exchange of the building and the environment, i.e. the dynamic behavior of the building, were analyzed for the purpose to obtain a realistic assessment of its thermal characteristics. In order to describe this phenomenon, the heat inertia of the insulation and coating material was used. The heat inertia describes the ability of a material or a building structure to store the heat energy and delay its transmission.

The thermal capacity of the massive envelope elements is defined by the phase shift. This paper analyzes the ability to temporarily delay the external thermal effect, as well as the attenuation factor of the outside temperature extremes on the inner side of the wall, which are the essential dynamic characteristics of the wall.

In order to obtain the optimal solution for the wall structure with the largest energysaving potential, three types of walls with similar structures, the same total thickness, but different layer thicknesses that make up the complete structure of the wall, were examined, as well as three cases of the same wall, but with the different positions of the thermal insulation layer.

Based on the results presented in this paper, it can be concluded that at walls with similar structures, the same total thickness, but different layer thicknesses that make up the complete structure of the wall, there are differences in delaying external temperature changes on the wall, whereas the position of the thermal insulation layer does not significantly affect temperature oscillation amplitude caused by external temperature change.

Taking all these into consideration, it is necessary to pay more attention to the study of the dynamic characteristics of certain types of walls and tend to find the optimal solutions which should meet all the legal requirements. On the one hand, these solutions would be economically sustainable, while on the other they would ensure the most possible comfort for the tenants.

Acknowledgements: The research was financially supported by the Ministry of Education, Science and Technological Development of the Republic of Serbia through Grants ON174001, TR34005 and III41017. A part of this research was published at the Symposium "Nonlinear Dynamics - Scientific work of Prof. Dr Katica (Stevanovic) Hedrih, Mathematical Institute of SASA, Belgrade, 4-6 September 2019. 
Responsible for the English language Slavica Stevanovic, ELT.

\section{REFERENCES}

1. Evangelisti, L., et al., Experimental investigation of the influence of convective and radiative heat transfers on thermal transmittance measurement, International Communications in Heat and Mass Transfer, 78, (2016), pp. 214-223.

2. Martin, K., et al., Equivalent wall method for dynamic characterization of thermal bridges, Energy and Buildings, 55, (2012), pp. 704-7143.

3. Biddulpha, P., et al., Inferring the thermal resistance and effective thermal mass of a wall using frequent temperature and heat flux measurements, Energy and Buildings, 78, (2014), pp. 10-16.

4. Johra, H., Heiselberg, P., Influence of internal thermal mass on the indoor thermal dynamics and integration of phase change materials in furniture for building energy storage: A review, Renewable and Sustainable Energy Reviews, 69, (2017), pp. 19-32.

5. Ferrariand, S., Zanotto, V., Building Energy Performance Assessment in Southern Europe, Springer, 2016.

6. M. Ljubenović, et al., The Impact of the Wall Structure on its Dynamic Characteristics, Proceedings, 18th Symposium on Thermal Science and Engineering of Serbia - SIMTERM 2017, Editors: Mirjana Laković Paunović i Mladen Stojiljković, Sokobanja, Serbia, 2017, pp 87-94.

7. The Rulebook on Energy Efficiency of Buildings, Official Gazette of the Republic of Serbia No. 61/2011.

8. Li, Z., et al., InSAR analysis of surface deformation over permafrost to estimate active layer thickness based on one-dimensional heat transfer model of soils, Scientific Reports, 5, 15542; doi:10.1038/srep15542, (2015).

9. G. Margani, (2010), Murature massive e comfort sostenibile in clima mediterraneo, http://www.poroton.it/ user/articoli/n68/murature-massive-comfort/murature-massive-comfort.aspx.

10. Kosssecka, E., Kosny, J., Equivalent wall as a dynamic model of a complex thermal structure, Journal of Building Physics, 20, (1997), pp. 249-268.

11. Standard EN ISO 13786

\section{DINAMIČKE KARAKTERISTIKE STRUKTURE ZIDA PRI PROCESU PRENOSA TOPLOTE}

U ovom radu je prikazan uticaj termičke mase materijala sa velikom gustinom, od kojeg su napravljeni zidovi, na dinamičke karakteristike structure višeslojnog zida izolacije zgrade pri procesu prenosa toplote. S obzirom da je konačni cilj dizajnirati zgradu sa najvećim stepenom korisnosti, to jest najmanjom potrošnjom energije za grejanje/hlađenje, potrebno je postići dobre termičke performance višeslojnog zida. Da bi se pronašlo optimalno rešenje strukture zida sa najvećim potencijalom uštede energije analizirane su različite structure zidova sa različitim debljinama slojeva, zatim zidovi istih struktura gde su razmatrane različite pozicije termoizolacionih slojeva. Na osnovu rezultata prikazanih u radu može se zaključiti da kod zidova sličnih struktura, iste ukupne debljine a različite debljine slojeva koje čine kompletnu strukturu zida, postoje razlike u kašnjenju promene spoljne temperature na zidu, dok sam raspored termoizolacionog sloja za jednu istu strukturu zida ne utiče izrazito na promenu oscilovanja temperature izazvanom promenom spoljašnje temperature.

Ključne reči: toplotna masa, specifična zidna masa, toplotna apsorpcija, periodični prenos toplote, faktor redukcije, toplotna inercija. 